\title{
Is Physical Medicine and Rehabilitation needed much more for COVID-19 pandemic?
}

\author{
Birkan Sonel Tur 10 , Deniz Evcik²@ \\ ${ }^{1}$ Department of Physical Medicine and Rehabilitation, Ankara University Faculty of Medicine, Ankara, Turkey \\ ${ }^{2}$ Department of Physical Medicine and Rehabilitation, Güven Hospital, Ankara, Turkey
}

Received: April 14, 2020 Accepted: April 16, 2020 Published online: April 18, 2020

The new coronavirus (COVID-19), which was previously termed severe acute respiratory syndrome coronavirus 2 (SARS-CoV-2), is a virus first identified on January $13^{\text {th }}, 2020$ as a result of a research conducted in a group of patients having respiratory symptoms (i.e., fever, cough, and shortness of breath) in Wuhan province of China in late December. ${ }^{[1]}$ The virus spreads quickly nationwide, from China to the whole world. Unfortunately, COVID-19 is not currently under control, and the pandemic has become the most important concern of our lives, affecting the whole globe, as well as Turkey. ${ }^{[1]}$

Huang et al. $^{[2]}$ first reported clinical features of 41 patients infected with COVID-19 who were working or visiting the local market selling seafood and live animals in Wuhan province. The initial symptoms included fever, cough, dyspnea, myalgia or fatigue, sputum production, headache, hemoptysis, and diarrhea. Almost all patients had bilateral lung ground-glass opacity on computed tomography imaging. ${ }^{[2]}$

The majority of COVID-19 patients present relatively mild clinical features. ${ }^{[3]}$ However, the disease is associated with significant morbidity and mortality, particularly in patients with older age or chronic medical conditions such as hypertension, diabetes mellitus, asthma, or chronic obstructive pulmonary disease. At least one-fifth of patients require supportive care in the intensive care unit (ICU). ${ }^{[4]}$ In a meta-analysis, despite the implementation of optimal supportive interventions, the case fatality rate among hospitalized patients was reported as $13.9 \% .^{[4]}$

The COVID-19 has a history of only about four months, which is a very short period of time. How long will this pandemic last? Will other types appear? Will it reappear when it ends? Currently, all these questions are waiting for answers.

In addition, the long-term outcomes of COVID-19 has not been fully understood, yet. Its long-term effects will emerge over time, as our clinical experiences increase. However, we can briefly classify the possible results as follows: 1 . Lung damage which may develop, particularly in severe pneumonia or acute respiratory distress syndrome (ARDS) cases; ${ }^{[4]} 2$. Complications of the intensive care process, such as immobilization; 3. Possible consequences and complications in the presence of neurological symptoms or disorders due to COVID-19; 4. Many problems including the lack of physical activity, changes in eating habits, insomnia, and psychological problems during quarantine or isolation period; ${ }^{[5]} 5$. Impaired functional capacity and quality of life resulting from all of the above; 6 . Finally, the social and economic aspects of the COVID-19 outbreak should be also kept in mind. ${ }^{[6,7]}$

The most worrying clinical pictures in COVID-19 are severe pneumonia and development of ARDS. The latter is a life-threatening organ failure which may be due to lung or extrapulmonary disorders. ${ }^{[8]}$ Today, in-hospital mortality due to ARDS is lower, compared to previous years; however, it still seems to

Corresponding author: Birkan Sonel Tur, MD. Ankara Üniversitesi Tıp Fakültesi Fiziksel Tıp ve Rehabilitasyon Anabilim Dalı, 06590 Çankaya, Ankara, Türkiye. 
be a risk factor for morbidity in elderly and patients with comorbidities. ${ }^{[9]}$ A wide range of obstructive and restrictive or only restrictive involvement can be detected in ARDS cases. Restrictive involvement may develop due to lung fibrosis and/or weakness of the respiratory muscles. Therefore, when an intensive care need occurs and/or ARDS arises due to severe pneumonia in patients with COVID-19, this can be a major and more serious problem. ${ }^{[10]}$ It is obvious that the results of these pulmonary problems, which we consider as the most important problem for the Physical Medicine and Rehabilitation (PMR) specialty, may require a comprehensive pulmonary rehabilitation approach in the coming period. In our country, the Cardiopulmonary Rehabilitation Working Group of our PMR societies has prepared guidelines for pulmonary rehabilitation of patients with COVID-19. ${ }^{[11,12]}$

It is well-known that acute rehabilitation in the ICU setting is very important in protecting the range of motion and muscle strength which has a close relationship with post-acute recovery. ${ }^{[13]}$ It is not surprising to speculate that the need for post-ICU rehabilitation for COVID-19 survivors will be growing due to prolonged immobilization and mechanical ventilation process. After tested negative for COVID-19, the PMR physician evaluates the functional level of the patient and plan rehabilitative strategies. These may include both inpatient rehabilitation or home-based care. ${ }^{[14,15]}$

Furthermore, we would like to draw attention to another aspect of the disease, which is less frequently mentioned at the moment. It is quite a new information that patients with COVID-19 may have also some neurological findings. ${ }^{[16]}$ Neurological complications in COVID-19 infected patients have not been widely reported, yet. Coronaviruses are neurotropic, and new coronavirus seems not to be an exception. ${ }^{[17]}$ Steardo et al. ${ }^{[17]}$ suggested that infected neurons and neuroglia and neuroinflammation might cause both acute and chronic neuropsychiatric problems and cognitive impairments. However, Tyler, $\mathrm{MD}$, a neuroinfectious disease expert, reported it was still unclear whether neurological complications were reflective of a direct viral injury or due to the secondary or systemic effects of infection. ${ }^{[18]}$

In addition, Mao et al. ${ }^{[16]}$ reported neurological findings in 214 hospitalized patients with a laboratoryconfirmed diagnosis of COVID-19 infection. Seventyeight (36.4\%) of the patients had neurological manifestations. Also, more severe patients were likely to have neurological symptoms $(45.5 \%$ vs. $30.2 \%)$, such as acute cerebrovascular diseases ( $5.7 \%$ vs. $0.8 \%)$, impaired consciousness ( $14.8 \%$ vs. $2.4 \%$ ), and skeletal muscle injuries (19.3\% vs. $4.8 \%) .{ }^{[16]}$ Similarly, Filatov et al. ${ }^{[19]}$ recently reported a 74 -year-old case presenting encephalopathy and suggested that elderly patients with chronic medical conditions were at an increased risk for altered mental status in the setting of acute infections. Steardo et al. ${ }^{[17]}$ also claimed that, for the patients with the neurological and psychiatric aspects of the COVID-19, should be considered while planning therapeutic strategies for rehabilitation paradigms.

Protecting the health of individuals isolated or quarantined at home or in the hospital setting is another issue. Although there is no direct evidence in COVID-19, recommendations for maintaining general health such as weight control, regulation of nutrition, physical activity, coping with stress, and quitting tobacco use should be kept in mind. ${ }^{[14,20]}$ Silver ${ }^{[20]}$ called these suggestions as prehabilitation. If these individuals have previous diseases which may cause disability, this process may be even more unfavorable for them. Their treatment and rehabilitation should be, therefore, individually tailored and followed.

On the other hand, infectious nature of the disease will be one of the most challenging obstacles in front of us, while providing the rehabilitation program in COVID-19 patients. The education of rehabilitation professionals on infection prevention methods, proper use of personal protective equipment, and environmental cleaning and waste management are the mainstays for personnel protection and for reducing the risk for COVID-19 transmission in the healthcare settings. ${ }^{[21,22]}$

In the near future, PMR physicians may face various problems related to rehabilitation and need to develop strategies rapidly during this time. One of these strategies is to use innovative approaches to rehabilitation during the COVID-19 outbreak. ${ }^{[14]}$ Using advanced communication techniques, telemedicine, or virtual reality in rehabilitation may be appropriate for such diseases. ${ }^{[14]}$ It is likely that we will need to diversify and improve these techniques, so that we can be more prepared for COVID-19 and similar situations which may occur in the future.

In conclusion, our goals should be focused on both to rehabilitate COVID-19 patients successfully and to protect the health of rehabilitation team members. A well and carefully designed rehabilitation program should be developed by the 
PMR specialty for COVID-19 patients. Nowadays, there are multifactorial, unknown problems for the management of pandemic and each country shows an extra effort to do their best in their own health care system. As PMR physicians, sharing our experiences in a network will bring light to others. ${ }^{[23]}$ Finally, in the future, we hope that the number of high-quality publications related to the rehabilitation field will increase, as the experiences with the management of COVID-19 increase.

\section{Declaration of conflicting interests}

The authors declared no conflicts of interest with respect to the authorship and/or publication of this article.

\section{Funding}

The authors received no financial support for the research and/or authorship of this article.

\section{REFERENCES}

1. WHO Disease Outbreak News. Available at: https://www. who.int/csr/don/en/ [Accessed: April 13, 2020]

2. Huang C, Wang Y, Li X, Ren L, Zhao J, Hu Y, et al. Clinical features of patients infected with 2019 novel coronavirus in Wuhan, China. Lancet 2020;395:497-506.

3. Wu Z, McGoogan JM. Characteristics of and Important Lessons From the Coronavirus Disease 2019 (COVID19) Outbreak in China: Summary of a Report of 72314 Cases From the Chinese Center for Disease Control and Prevention. JAMA 2020;323:1239-42.

4. Rodriguez-Morales AJ, Cardona-Ospina JA, GutiérrezOcampo E, Villamizar-Peña R, Holguin-Rivera Y, EscaleraAntezana JP, et al. Clinical, laboratory and imaging features of COVID-19: A systematic review and meta-analysis. Travel Med Infect Dis 2020:101623.

5. Qian M, Wu Q, Wu P, Hou Z, Liang Y, Cowling BJ, et al. Psychological responses, behavioral changes and public perceptions during the early phase of the COVID19 outbreak in China: a population based cross-sectional survey. medRxiv 2020.

6. Burdorf A, Porru F, Rugulies R. The COVID-19 (Coronavirus) pandemic: consequences for occupational health. Scand J Work Environ Health 2020.

7. Atkeson A. What Will Be the Economic Impact of COVID19 in the US? Rough Estimates of Disease Scenarios. NBER Working Paper No. 268672020.

8. Chiumello D, Coppola S, Froio S, Gotti M. What's Next After ARDS: Long-Term Outcomes. Respir Care 2016;61:689-99.

9. Sigurdsson MI, Sigvaldason K, Gunnarsson TS, Moller A, Sigurdsson GH. Acute respiratory distress syndrome: nationwide changes in incidence, treatment and mortality over 23 years. Acta Anaesthesiol Scand 2013;57:37-45.

10. Herridge MS, Cheung AM, Tansey CM, Matte-Martyn A, Diaz-Granados N, Al-Saidi F, et al. One-year outcomes in survivors of the acute respiratory distress syndrome. N Engl J Med 2003;348:683-93.
11. COVID-19 Sonrası pulmoner rehabilitasyon. Türkiye Fiziksel Tip ve Rehabilitasyon Derneği \& Türkiye Fiziksel Tıp ve Rehabilitasyon Uzman Hekimleri Derneği. Erişim linki: http://www.tftr.org.tr/uploads/Covid-19-PulmonerRehabilitasyon.pdf [Erişim tarihi: 13 Nisan 2020]

12. Kurtaiş Aytür Y, Köseoğlu BF, Özyemişçi Taşkıran Ö, Ordu Gökkaya NK, Ünsal Delialioğlu S, Sonel Tur B, et al. Türkiye Fiziksel Tip ve Rehabilitasyon Derneği \& Türkiye Fiziksel Tip ve Rehabilitasyon Uzman Hekimleri Derneği Kardiyopulmoner Rehabilitasyon Çalışma Grubu, Sars-cov-2 (COVID-19) sonrası pulmoner rehabilitasyon prensipleri: akut ve subakut sürecin yönetimi için rehber. 13 Nisan 2020, Versiyon 1.0. Erişim linki: http://www.tsprm. org/pdf_free/COVID-19_FTR_Pulmoner.pdf [Erişim tarihi: 13 Nisan 2020]

13. van der Schaaf M, Beelen A, Dongelmans DA, Vroom MB, Nollet F. Poor functional recovery after a critical illness: a longitudinal study. J Rehabil Med 2009;41:1041-8.

14. Simpson R, Robinson L. Rehabilitation following critical illness in people with COVID-19 infection. Am J Phys Med Rehabil 2020. [Epub ahead of print]

15. Smith JM, Lee AC, Zeleznik H, Coffey Scott JP, Fatima A, Needham DM, et al. Home and Community-Based Physical Therapist Management of Adults With Post-Intensive Care Syndrome. Phys Ther 2020 Apr 13. pii: pzaa059. [Epub ahead of print]

16. Mao L, Jin $\mathrm{H}$, Wang $\mathrm{M}, \mathrm{Hu} \mathrm{Y}$, Chen $\mathrm{S}, \mathrm{He} \mathrm{Q}$, et al. Neurologic Manifestations of Hospitalized Patients With Coronavirus Disease 2019 in Wuhan, China. JAMA Neurol 2020:e201127.

17. Steardo L, Steardo L Jr, Zorec R, Verkhratsky A. Neuroinfection may contribute to pathophysiology and clinical manifestations of COVID-19. Acta Physiol (Oxf) 2020:e13473.

18. Fitzgerald S. The Spread of COVID-19: Questions Raised, Some Answered by Neuroinfectious Disease Experts. Available at: https://journals.lww.com/neurotodayonline/ fulltext/2020/04020/the_spread_of_covid_19__questions_ raised,_some.1.aspx [Accessed: April 2, 2020]

19. Filatov A, Sharma P, Hindi F, Espinosa PS. Neurological Complications of Coronavirus Disease (COVID-19): Encephalopathy. Cureus 2020;12:e7352.

20. Silver JK. Prehabilitation could save lives in a pandemic. BMJ 2020. Available at: https://blogs.bmj.com/ bmj/2020/03/19/julie-k-silver-prehabilitation-could-savelives-in-a-pandemic/ [Accessed: April 11, 2020]

21. Rational use of personal protective equipment for coronavirus disease (COVID-19). Available at: https://apps.who.int/ iris/bitstream/handle/10665/331498/WHO-2019-nCoVIPCPPE_use-2020.2-eng.pdf [Accessed: April 2, 2020]

22. Infection prevention and control and preparedness for COVID-19 in healthcare settings. Available at: https://www. ecdc.europa.eu/sites/default/files/documents/Infectionprevention-control-for-the-care-of-patients-with-2019nCoV-healthcare-settings_update-31-March-2020.pdf [Accessed: April 11, 2020]

23. Negrini S, Ferriero G, Kiekens C, Boldrini P. Facing in real time the challenges of the Covid-19 epidemic for rehabilitation. Eur J Phys Rehabil Med 2020. 